\title{
Connective Tissue Nevus
}

National Cancer Institute

\section{Source}

National Cancer Institute. Connective Tissue Nevus. NCI Thesaurus. Code C8371.

A hamartoma characterized by localized malformation of one or more of the components of the dermis; presenting as clustered, slightly raised, pea-sized lesions distributed over the abdomen, back, buttocks, arms, or thighs. It may be an isolated lesion or a component of one of a number of inherited disorders, such as tuberous sclerosis. 